\title{
Pola Pemberian Reward dan Pengaruhnya Terhadap Motivasi Siswa dalam Pembelajaran Bahasa Arab
}

\author{
Nurwulan Mahfud \\ Institut Agama Islam Negeri (IAIN) Syekh Nurjati Cirebon \\ Email: wulanmahfud9@gmail.com \\ Rodliyah Zaenuddin \\ Institut Agama Islam Negeri (IAIN) Syekh Nurjati Cirebon \\ Email: rodliyahz@gmail.com
}

\section{الملخص}

أهداف هذا البحث لمعرفة أنماط إعطاء الهدايا في ترقية دوافع الطلاب في تعلم اللغة العربية بمدرسة دار المصالح المتوسطة الإسلامية شربون و لمعرفة تصور الطلاب إلى الهدايا في ترقية دوافع الطلاب

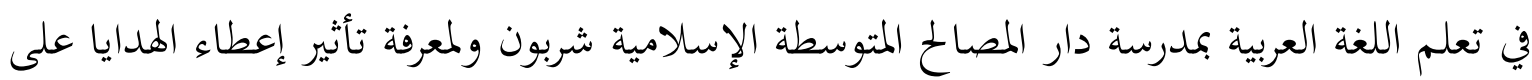
دوافع الطلاب في تعلم اللغة العربية بمدرسة دار المصالح المتوسطة الإسلامية شربون. وقفت الباحثة على أن أنماط إعطاء المدايا إلى الطلاب في تعلم اللغة العربية في الفصل الثامنب بمدرسة دار المصالح الإسلامية شربون هي شكل إعطاء الهدايا للطلاب الذين ينالون الإبحاز.

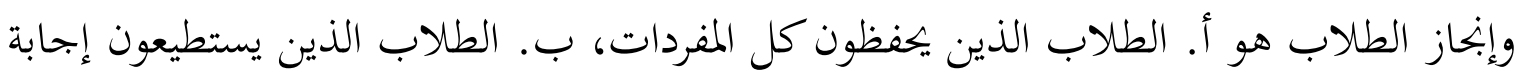
السؤال ، ج. الطلاب الذين يعملون الواجبات. بعد أن يتم التعلم من اللقاء الأول إلى اللقاء

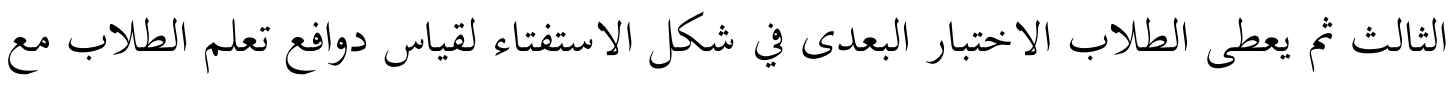

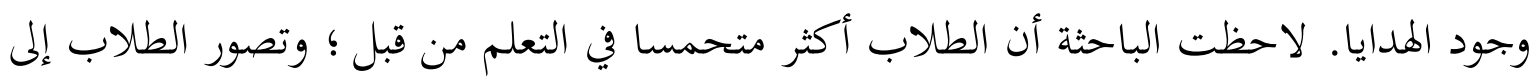
الهدايا في ترقية دوافع طلاب في الفصل الثامن في تعلم اللغة العربية بمدرسة دار المصالح المتوسطة الإسلامية شربون كما يلي: بناء على نتيجة خلاصة الاستفتاء الإيجابي يدل على الطلاب يجيبون موافقا جدا 43 \% وموافقا 46\% وغير موافق 8\% وغير موافق جدا 3\% بــ وبناء على الاستفتاء

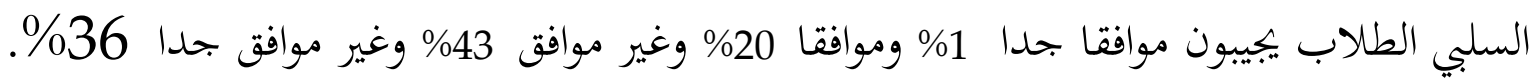
ولذلك يستطيع إعطاء المدايا أن يرقي دوافع الطلاب في تعلم اللغة العربية و م من البيانات

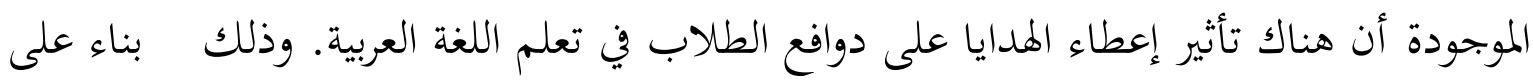
نتائج اختبار الانحدار (regression test) لها نتيجة دلالية من 0.001. ولأن نتيجة دلالية أصغر من 


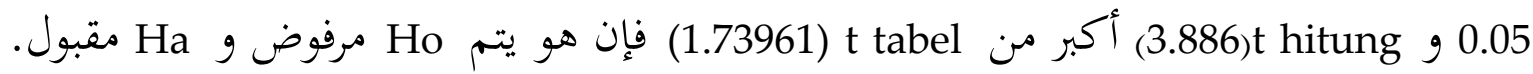

$$
\begin{aligned}
& \text { وهذا المعنى أن إعطاء المدايا يؤثر على دوافع الطلاب في تعلم اللغة العربية. } \\
& \text { وأما مناهج البحث في هذه الرسالة هي البحث الكمي باستخدام طريقة Pre-Experimental } \\
& \text { Design } \\
& \text { البيانات في هذا البحث باستخدام الاستفتاء. أساليب تحليل البيانات باستخدام بتحربة العادة و } \\
& \text { تجربة المتجانس وبتحبة الفرضية. } \\
& \text { الكلمات الرئيسية: الهدايا، دوافع الطلاب، تعلم اللغة العبية }
\end{aligned}
$$

\begin{abstract}
Abstrak
Penelitian ini bertujuan untuk mengetahui pola pemberian reward terhadap motivasi siswa dalam belajar Bahasa Arab, mengetahui persepsi siswa terhadap reward dalam meningkatkan motivasi belajar Bahasa Arab, dan mengetahui pengaruh pemberian reward terhadap motivasi siswa dalam belajar Bahasa Arab di MTs Darul Masholeh Cirebon.

Artikel ini menyimpulkan bahwa siswa lebih semangat dalam belajarnya. Berikut ini persepsi siswa terhadap reward dalam meningkatkan motivasi siswa di kelas VIII di MTs Darul Masholeh Cirebon. Berdasarkan hasil rekapitulasi angket positif menunjukkan bahwa siswa yang menjawab sangat setuju $43 \%$, setuju $46 \%$, tidak setuju $8 \%$, dan sangat tidak setuju 3\%. Dan berdasarkan rekapitulasi angket negatif siswa yang menjawab sangat setuju $1 \%$, setuju $20 \%$, tidak setuju $43 \%$, dan sangat tidak setuju $36 \%$. Oleh karena itu pemberian reward dapat meningkatkan motivasi siswa dalam pembelajaran Bahasa Arab. (3) Dari data yang ada terdapat pengaruh pemberian reward terhadap motivasi siswa dalam belajar Bahasa Arab. Hal ini berdasarkan hasil uji regresi dengan hasil 0,001. Karena hasilnya lebih kecil dari 0,05 dan $t$ hitung $(3,886)$ lebih besar dari t tabel $(1,73961)$, maka Ho ditolak dan Ha diterima. Ini berarti pemberian hadiah mempengaruhi motivasi belajar bahasa Arab.

Peneliti menggunakan Pre-Experimental Design dengan pendekatan kuantitatif. Desain penelitian yang digunakan yaitu One-Shot Case Study Design. Teknik pengumpulan data yang digunakan dalam penelitian ini yaitu angket. Adapun teknik analisis data yang digunakan adalah uji normalitas, uji homogenitas, dan uji hipotesis.
\end{abstract}

Kata Kunci: Pemberian Reward, Motivasi Siswa, Belajar Bahasa Arab

\title{
Pendahuluan
}

Pendidikan adalah serangkaian kegiatan yang dirancang untuk memungkinkan siswa belajar. ${ }^{1}$ Wina Sanjaya mengatakan bahwa pendidikan sebagai proses organisasi lingkungan bertujuan untuk mengubah perilaku siswa

${ }^{1}$ Rusmono, Strategi Pembelajaran dengan Problem Based Learning Itu Perlu. (Bogor: Ghalia Indonesia, 2014). Hal. 6 
ke arah yang positif dan lebih baik dengan potensi dan perbedaan individu yang melekat. ${ }^{2}$ Sedangkan proses belajar mengajar merupakan proses interaktif antara dua unsur manusia, yaitu pelajar dan guru yang mengajar, siswa sebagai subjek utama. ${ }^{3}$ Dengan adanya proses pembelajaran diharapkan terdapat perubahan pada diri siswa baik dalam aspek kognitif, afektif, maupun psikomotor.

Belajar bahasa asing bukanlah sesuatu yang mudah. Hal ini membutuhkan banyak faktor, seperti metode yang baik, pendekatan yang tepat, dan faktor-faktor yang berkaitan dengan pokok bahasan untuk mencapai tujuan pendidikan secara memuaskan. ${ }^{4}$

Di antara faktor yang dapat membantu mencapai tujuan pendidikan yang memuaskan adalah motivasi karena dapat mendorong siswa untuk belajar. Membentuk motivasi belajar adalah salah satu cara seorang guru dalam mengatasi kesulitan belajar siswa. Donald mengatakan bahwa motivasi adalah perubahan energi pada diri seseorang yang ditandai dengan munculnya perasaan dan didahului dengan tanggapan terhadap tujuan. ${ }^{5}$

Berdasarkan makna fungsional motivasi dapat dibentuk dengan berbagai cara, salah satunya dengan penghargaan dan sanksi sebagai akibat hasil proses belajar siswa. ujuan memberikan hasil ini untuk membentuk keinginan terbaik untuk belajar. ${ }^{6}$ Hasil yang menyenangkan umumnya disebut reward. ${ }^{7}$

Penghargaan adalah alat untuk mendidik siswa agar merasa bahagia karena pekerjaan yang telah mereka lakukan dan telah mendapatkan imbalan atau hadiah. ${ }^{8}$ Penghargaan/reward adalah salah satu bentuk penguatan positif. Menurut Skiner (tokoh behavioristik) elemen terpenting dalam pembelajaran adalah penguatan yang terbentuk melalui hubungan stimulus dan respon akan mendorong peningkatan penguatan. ${ }^{9}$ Dalam hal ini reward sebagai insentif bagi siswa untuk meningkatkan respon yang diberikan oleh siswa berupa motivasi belajar pasif. Efek penghargaan dalam pembelajaran adalah membuat siswa mengulangi apa yang mereka lakukan dan menyebabkan perilaku terus berlanjut.

Berdasarkan survei pada tanggal 5 Mei 2017 di MTs Darul Masholeh, sebuah penelitian dilakukan pada dua puluh siswa di kelas VII A, terdiri dari dua belas siswa dan delapan siswa yang terkait dengan pengajaran bahasa Arab. hasilnya adalah sebagai berikut:

\footnotetext{
${ }^{2}$ Lihat Wina Sanjaya, Pembelajaran dalam Implementasi Kurikulum Berbasis Kompetensi. (Jakarta: Kencana 2008).

3 Sardiman, Interaksi dan Motivasi Belajar Mengajar. (Jakarta : Rajawali Press, 2014). Hal. 14. 4 عبد الرحمن إبراهيم فوزان، دروس الدورات التدريبية لمعلمي اللغة العربية لغير الناطقين بها (مشروع العربية للجميع، 1425 هـ )

5 Sardiman, Interaksi dan Motivasi Belajar Mengajar.... Hal. 73.

6 Sardiman, Interaksi dan Motivasi Belajar Mengajar.... Hal. 73.

7 Ratna Wilis Dahar, Teori-teori Belajar dan Pembelajaran. (Jakarta : Erlangga, 2011). Hal. 20.

8 Ngalim Purwanto, Ilmu Pendidikan Teoritis dan Praktis. (Bandung: PT Remaja Rosdakarya,2007). Hal. 182.

${ }^{9}$ C. Asri Budiningsih, Belajar dan Pembelajaran. (Jakarta: PT Rineka Cipta, 2005). Hal. 25.
} 
1. Siswa belajar karena tuntutan dari sekolah

Sangat setuju 40\% (8 orang), setuju 25\% (5 orang), kurang setuju 20\% (4 orang), tidak setuju 5\% (1 orang), tidak berhubungan 10\% (2 orang).

2. Jika siswa mendapatkan tugas bahasa Arab mereka merasa terbebani dengan pekerjaan mereka

Sangat setuju 55\% (11 0rang), setuju 10\% (2 orang), kurang setuju 15\% (3 orang), tidak setuju 10\% (2 orang), tidak berhubungan 10\% (2 orang).

3. Bila guru bahasa Arab tidak masuk kelas, siswa merasa senang Sangat setuju 26\% (6 0rang), setuju 35\% (8 orang), kurang setuju 13\% (3 orang), tidak setuju 9\% (2 orang), tidak berhubungan 17\% (4 orang).

Berdasarkan survei menunjukkan bahwa motivasi siswa untuk belajar bahasa Arab pada kelas VII-A tahun ajaran 2016-2017 rendah, sehingga perlu berusaha untuk meningkatkan motivasi, disisi lain nilai ujian harian siswa pada kelas VII tahun ajaran 2016 - 2017 di MTs Darul Masholeh, yang dilakukan pada hari Kamis, 6 April 2017, yang diikuti oleh 21 siswa. Dari 21 siswa, 29\% (enam orang) hanya mencapai KKM, sementara siswa yang tidak mencapai KKM adalah 71\% (15\%). Nilai KKM di MTs Darul Masholeh adalah 70, sedangkan nilai ratarata tes harian di kelas VII adalah 62.

Berdasarkan permasalahan di atas, peneliti mencoba meningkatkan motivasi siswa untuk belajar bahasa Arab di kelas VII-A dengan memberi reward berupa hadiah. Dengan pemberian hadiah ini diharapkan siswa lebih semangat dalam proses pembelajarannya, terutama dalam bahasa Arab.

Bertitik tolak dari penjelasan latar belakang masalah yang telah dikemukakan, maka Sejauh mana persepsi dan pengaruh pemberian hadiah terhadap motivasi siswa dalam belajar Bahasa Arab di MTs Darul Masholeh Cirebon?

\section{Metode Penelitian}

Metode penelitian yang digunakan dalam penelitian ini adalah PreExperimental Design dengan pendekatan kuantitatif untuk mengetahui pengaruh pemberian hadiah terhadap peningkatan motivasi siswa dalam belajar Bahasa Arab. Variabel adalah subjek penelitian atau apa yang menjadi titik perhatian dalam penelitian. Berdasarkan penelitian ini ada pengaruh pada perlakuan, dan kemudian ada variabel yang berpengaruh dan variabel yang dipengaruhi. Variabel yang berpengaruh disebut variabel independen $(X)$ dan variabel yang dipengaruhi disebut variabel non-independen $(Y) .{ }^{10}$

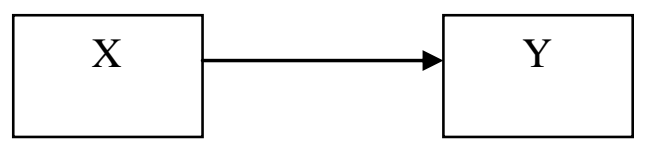

10 Suharsimi Arikunto, Prosedur Penelitian Suatu Pendekatan Praktik. (Jakarta: PT Rineka Cipta 2013). Hal. 162. 
Ket:

Variabel $\mathrm{X}=$ Pola pemberian reward

Variabel $Y=$ Motivasi siswa dalam belajar Bahasa Arab

= Pengaruh pemberian reward terhadap motivasi siswa

dalam belajar Bahasa Arab

Desain yang digunakan dalam penelitian ini adalah One - Shot Case Study Design. Dalam desain ini ada sebuah kelompok diberikan perlakuan, kemudian hasilnya diamati. ${ }^{11}$ Dalam penelitian ini variabel independen, maka hipotesis penelitian tersebut bukan dalam bentuk perbandingan atau hubungan antara dua variabel atau lebih. ${ }^{12}$ Adapun bentuk desainnya sebagai berikut:

Ket:

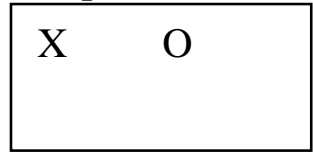

$\mathrm{X}=$ treatment yang diberikan (variabel independen)

$\mathrm{O}=$ observasi (variabel dependen)

Lokasi penelitian dilakukan di MTs Darul Masholeh Kec. Harjamukti Kota Cirebon.

Berdasarkan sumbernya, data yang digunakan oleh peneliti untuk memeroleh informasi dalam penelitian ini yaitu sumber data primer dan sumber data sekunder. Sumber data primer dalam penelitain ini yaitu siswa kelas VIII B di MTs Darul Masholeh Cirebon dan sumber data sekundernya yaitu buku-buku yang berhubungan dengan penelitian ini.

Populasi dalam penelitian ini yaitu semua siswa kelas VIII di MTs Darul Masholeh Cirebon yang terdiri dari 42 siswa. Adapun sampelnya yaitu semua siswa kelas VIII-B di MTs Darul Masholeh Cirebon dengan teknik pengambilan sampel "Cluster Sampling".

Metode pengumpulan data dalam penelitian ini yaitu dengan menggunakan observasi dan angket. Observasi yang digunakan yaitu observasi pastisipan dimana peneliti terlibat dengan kegiatan sehari-hari orang yang sedang diamati atau yang digunakan sebagai sumber data penelitian. ${ }^{13}$ Dan angket yang digunakan oleh peneliti yaitu angket langsung, dimana angket dikirim dan diisi oleh orang yang akan diminta jawabannya. Kemudian dilihat dari jawabannya angket terdiri dari angket terbuka dan angket tertutup. Angket yang digunakan dalam penelitian ini yaitu angket tertutup yakni angket diatur dengan memberikan jawaban penuh sehingga responden memberikan tanda pada jawaban yang dipilih. ${ }^{14}$

\footnotetext{
11 Sugiyono, Metode Penelitian Pendidikan (Bandung: Alfabeta 2015). Hal. 110.

12 Sugiyono, Metode Penelitian Pendidikan (Bandung: Alfabeta 2007). Hal. 9.

13 Sugiono, Metode Penelitian Manajemen (Bandung: Alfabeta, 2016). Hal. 235.

14 Suharsimi Arikunto, Prosedur Penelitian Suatu Pendekatan Praktik .... Hal. 268.
} 
Instrumen penelitian yang digunakan dalam penelitian ini adalah angket. Angket sebagai instrumen pengumpulan data ordinal yang merupakan penjabaran dari indikator variabel sebelum digunakan untuk mengumpulkan data di lapangan terlebih dahulu harus diuji tingkat validitas dan reabilitasnya. Untuk menguji tingkat validitas dan reliabilitas instrumen penelitian akan diujikan kepada 20 responden. Penghitungan uji validitas data ini dengan menggunakan microsoft excel 2007 dan SPSS 16 ((Statistical Package For the Social Science). Rumus yang digunakan adalah pearson product moment.

Ket:

$$
r=\frac{N \sum x y-\left(\sum x\right)\left(\sum y\right)}{\sqrt{\left(N \sum x^{2}\right.}-\left(\sum x\right)^{2}\left(N \sum y^{2}-\left(\sum y\right)^{2}\right.}
$$

$\mathrm{R}=$ koefisien korelasi antara variabel $\mathrm{X}$ dan variabel $\mathrm{Y}$

$\mathrm{X}=$ variabel bebas

$\mathrm{Y}=$ variabel terikat

$\Sigma \mathrm{x}=$ jumlah skor item

$\Sigma \mathrm{y}=$ jumlah skor total item

$\Sigma \mathrm{x}^{2}=$ jumlah perkalian kuadrat dari hasil nilai skor variabel bebas

$\Sigma y^{2}=$ jumlah perkalian kuadrat dari hasil nilai skor variabel

$\mathrm{N}=$ jumlah sampel

Adapun pengujian reabilitas ini menggunakan microsoft excel 2007 dan SPSS 16 ((Statistical Package For the Social Science) dengan rumus Cronbach's Alpha.

Ket:

$$
r_{11}=\left(\frac{k}{(k-1)}\right)\left(1-\frac{\sum \sigma b^{2}}{\sigma^{2} t}\right)
$$

$r_{11}=$ reabilitas instrumen

$\mathrm{k}=$ jumlah soal

$\sum \sigma b^{2}=$ kelompok perbedaan soal

$\sigma^{2} t=$ jumlah kelompok awal dikurangi jumlah kelompok akhir

Analisis data dalam penelitian ini menggunakan uji normalitas, uji homogenitas, dan uji hipotesis.

\section{Konsep Hadiah}

Penghargaan atau reward adalah alat pendidikan yang diberikan ketika siswa mengerjakan sesuatu yang baik atau mencapai tahap perkembangan tertentu atau mencapai tujuan. ${ }^{15}$ Pengertian reward memiliki ruang lingkup yang luas yang meliputi semua bidang. Dalam bidang pendidikan, reward/penghargaan memiliki pengertian khusus.

15 Aris Shoimin, 68 Model Pembelajaran Inovatif dalam Kurikulum 2013. (Yogyakarta: Ar-Ruzz Media, 2014). Hal. 157. 
Menurut Hamalik reward adalah sarana untuk mendorong motivasi belajar siswa. ${ }^{16}$ Slameto menambahakan bahwa reward adalah bentuk perhatian dan pengangkatan motivasi siswa yang berguna untuk mendorong siswa agar berusaha keras untuk mencapai tujuan pendidikan. ${ }^{17}$ Berdasarkan pengertianpengertian tersebut dapat disimpulkan bahwa reward adalah sebuah bentuk atau cara yang digunakan oleh guru untuk menggerakkan dan memperkuat motivasi belajar siswa di sekolah untuk mencapai tujuan pendidikan.

Reward memiliki peran penting dalam pembelajaran seperti faktor eksternal dalam memengaruhi dan mengarahkan sikap siswa. Hal ini didasarkan pada berbagai pertimbangan logis seperti pemberian ini dapat menyebabkan motivasi belajar siswa dan dapat mempengaruhi perilaku positif dalam kehidupan siswa adalah cara memberi hadiah dan evaluasi positif sehingga siswa dapat mengembangkan self-realisasi dan konsep diri yang positif. ${ }^{18}$

Manusia selalu memiliki cita-cita, harapan dan keinginan. Ini adalah keuntungan dari metode pemberian hadiah. Cara ini dilakukan oleh seseorang untuk melakukan pekerjaan dengan baik atau mencapai prestasi tertentu karena mendapat hadiah yang menarik sebagai gantinya. ${ }^{19}$

Berkaitan dengan reward, di dalam Al-Qur'an ada ayat-ayat tentang memberi hadiah atau penghargaan di bidang pendidikan. Salah satunya adalah Surat al-'Imran, 136:

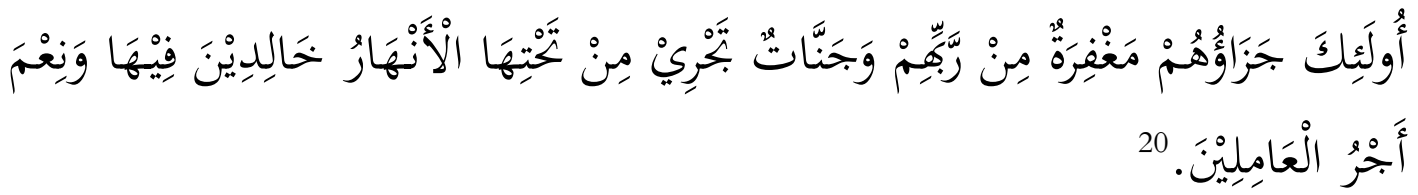

Dengan memberi hadiah, siswa akan belajar lebih banyak untuk meningkatkan prestasi mereka. Dengan kata lain, siswa akan melakukan pekerjaan yang baik atau lebih baik dan lebih rajin.

Pemberian penghargaan/reward harus didasarkan pada prinsip-prinsip sebagaimana dijelaskan oleh Subchy Fikri sebagai berikut ${ }^{21}$ :

a. Penilaian didasarkan pada perilaku bukan pada pelaku perilaku. Untuk membedakan antara pelaku dan perilaku masih sulit. Terutama kebiasaan dan persepsi yang tertanam dalam mentalitas kita yang sering sama

${ }^{16}$ Oemar Hamalik, Kurikulum dan Pembelajaran. (Jakarta : Bumi Aksara 2011). Hal. 166.

17 Slameto, Belajar dan Faktor-Faktor yang Mempengaruhinya. (Jakarta: Rineka Cipta, 2010). Hal. 176

18 Desmita, Psikologi Perkembangan Peserta Didik. (Bandung: Remaja Rosdakarya, 2011). Hal. 86.

${ }^{19}$ HM Arifin, Ilmu Pendidikan Islam. (Jakarta: Bumi Aksara, 2009). Hal. 70-71

20Departemen Agama RI, Al-Qur'an Al-Kafi. (Bandung: CV Penerbit Diponegoro, 2006). Hal. 68.

${ }^{21}$ Subchi Al-Fikri, "Penghargaan (Reward) dan Hukuman (Punishment) dalam Pendidikan Islam". http://myopera.com/blog, diakses tanggal 11 Agustus 2017. 
dengan dua hal ini. Istilah seperti anak baik dan anak cerdas, yang menandakan sifat pelaku, bukanlah alasan pemberian penghargaan karena akan berujung pada persepsi bahwa kelahiran anak dapat ditemukan dan bisa hilang. Tapi perilaku anak yang menerima hadiah itu harus disebutkan secara langsung.

b. Pemberian penghargaan itu harus diberi batas. Memberi penghargaantidak dapat selamanya digunakan. Proses ini berjalan sampai tahap pertumbuhan kebiasaan saja. Bila proses pembiasaan dianggap cukup, maka pemberian harus diakhiri. Yang paling penting yang harus dilakukan adalah memberi pemahaman sesegera mungkin kepada anakanak tentang pembatasan ini.

c. Penghargaan itu merupakan bentuk perhatian. Alternatif pemberian terbaik bukanlah dalam bentuk materi melainkan dalam bentuk perhatian verbal maupun fisik. Dan perhatian lisan bisa menjadi komentar bilateral seperti subhaanallah, alhamdulillah, betapa lukisanmu. Perhatian fisik bisa jadi pelukan atau jempol ke atas.

d. Pemberian penghargaan harus didiskusikan sampai mencapai kesepakatan. Seluruh siswa ditanya tentang hadiah yang dibutuhkan, Tentu mereka akan mengingat unsur-unsur yang mereka cintai. Hal ini membutuhkan kecerdasan dan kesabaran guru atau orang tua untuk berdialog dan memahami secara detail sesuai dengan kemampuan berpikir siswa, sehingga tidak semua keinginan kita dapat terpenuhi.

e. Pemberian hadiah berdasarkan proses bukan berdasarkan hasil. Banyak orang lupa bahwa proses lebih penting daripada hasil. Proses pendidikan yang merupakan upaya para siswa adalah perjuangan sesungguhnya. Sedangkan hasil yang akan didapat nantinya tidak bisa menjadi kriteria keberhasilannya.

Tujuan pemberian reward yang utama adalah: ${ }^{22}$

a. Menarik (Attract)

Reward harus mampu menarik orang yang berkualitas untuk menjadi anggota organisasi.

b. Mempertahankan (Retain)

Reward juga bertujuan untuk mempertahankan pegawai dari incaran organisasi lain. Sistem reward yang baik dan menarik mampu meminimalkan jumlah pegawai yang keluar.

c. Memotivasi (Motivate)

Sistem reward yang baik harus mampu meningkatkan motivasi pegawai untuk mencapai prestasi yang tinggi.

22 Gibson, Organisasi, Perilaku, Struktur, dan Proses. (Jakarta: Erlangga, 1997). Hal 169. 
Tujuan-tujuan tersebut oleh Gibson diarahkan kepada karyawan. Tetapi bisa kita terapkan dalam proses pembelajaran di dalam kelas. Dalam hal ini, pemberian hadiah bertujuan untuk menarik minat siswa mengikuti proses belajar mengajar, mempertahankan prestasi dan mendorong siswa untuk meningkatkan prestasi akademik mereka.

\section{Konsep Motivasi}

Dalam pengertian secara istilah, motivasi adalah kekuatan psikologis batin yang menggerakkan seseorang untuk mewujudkan perilaku spesifik untuk mencapai tujuan tertentu. ${ }^{23}$

Wlodkowski, yang dikutip oleh Siregar, mengatakan bahwa motivasi sebagai suatu kondisi yang menyebabkan perilaku tertentu dan memberi bimbingan dan ketahanan dalam berperilaku. ${ }^{24}$

Sheikh Kamel Mohammed 'Awidhah, mengemukakan bahwa motivasi adalah energi potensial objek, yang menentukan tujuan perilaku dan membuka jalan untuk memenuhi kebutuhannya. ${ }^{25}$

Adapun konsep motivasi yang merupakan konsep kontroversial dalam psikologi yaitu bahwa motivasi adalah keadaan internal dalam organisme organik atau pembentukan hipotesis yang dapat dibuka dari bukti perilaku berikut: ${ }^{26}$

a. Meningkatkan jumlah energi

b. Merangsang kebutuhan tertentu dalam organisme

c. Meningkatkan ketegangan organisme organik

d. Mengorganisir dan membimbing perilaku

e. Adaptasi terhadap kondisi eksternal

Secara umum motivasi terbagi menjadi dua jenis yaitu motivasi intrinsik dan motivasi ekstrinsik. 1) Motivasi intrinsik adalah motivasi yang tidak perlu digerakkan dari luar, karena setiap individu (siswa) memiliki keinginan untuk melakukan sesuatu. Motivasi ini juga disebut motivasi asli dan motivasi yang sebenarnya adalah impuls yang muncul dari dalam diri. Motivasi intrinsik ini adalah motivasi yang hidup pada diri siswa dan berguna untuk motivasi belajar fungsional. Dalam hal ini, reward tidak dibutuhkan karena tidak mempengaruhi siswa. Ini berarti motivasi tumbuh pada diri siswa tanpa faktor eksternal. 2) Motivasi eksternal adalah stimulan aktif dan memiliki fungsi karena adanya pendorong dari luar. Dapat dikatakan bahwa motivasi eksternal adalah bentuk motivasi di mana kegiatan belajar dimulai dan berlanjut berdasarkan dorongan dari luar yang berkaitan dengan kegiatan belajar seperti pemberian hadiah,

23 رشدي أمد طعيمة، المرجع فى تعليم اللغة العربية للناطقين بلغات أخحىى ـ الجزء الأول (جامعة أم القرى معهد اللغة العربية، 1986). ص. 260

24 Eveline Siregar \& Hartini Nara, Teori Belajar dan Pembelajaran. (Bogor: Ghalia Indonesia, 2011). Hal. 49.

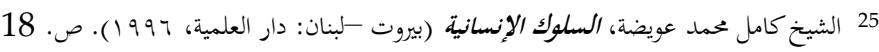

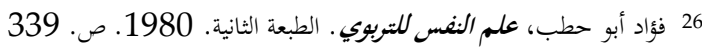


sertifikat, nilai, dll. Dalam kegiatan belajar dan mengajar, motivasi eksternal penting karena memungkinkan siswa dinamis dan transformatif. Dalam kegiatan ini ada sesuatu yang kurang menarik sehingga motivasi eksternal. ${ }^{27}$

Motivasi memiliki dampak yang besar dalam belajar bahasa kedua. Terdapat perbedaan pendapat para psikolog mengenai dampak ini, namun mereka mengumpulkan dua fakta penting: Pertama, di belakang siswa terdapat motivasi yang mendorongnya, dan motivasi untuk belajar sesuatu yang diklaim selesai, dan mencapai tujuannya, terutama dalam bentuknya yang kompleks, dan keterampilan interpersonal, dan kedua: di balik banyak kegagalan belajar terdapat kehilangan motivasi. ${ }^{28}$

Nasution (2004: 75) mengemukakan bahwa motivasi memiliki peran dan fungsi penting dalam belajar, yaitu:

a. Merupakan penggerak yang memotivasi untuk melakukan kegiatan belajar untuk mencapai tujuan yang diinginkan.

b. Menentukan arah proses pembelajaran kepada tujuan yang diinginkan.

c. Memilih kegiatan dalam belajar untuk mencapai tujuan yang diinginkan.

De Decce dan Grawford dikutip oleh Syaiful Bahri mengemukakan bahwa ada empat pekerjaan sebagai guru dalam mempertahankan dan meningkatkan motivasi belajar siswa, memberikan harapan yang realistis, memberikan insentif, dan membimbing perilaku siswa terhadap tujuan pendidikan. ${ }^{29}$

a. Mendorong siswa

Guru harus menghindari hal-hal yang monoton dan membosankan. Siswa harus selalu diberikan cukup banyak hal untuk dipikirkan dan dilakukan. Guru harus menjaga keinginan siswa untuk belajar, dengan memberikan kebebasan tertentu untuk berpindah dari satu sisi ke aspek pelajaran dalam situasi belajar.

b. Memberikan harapan yang realistis

Guru perlu mengetahui tentang keberhasilan akademis atau kegagalan setiap siswa di masa lalu. Jika siswa mengalami banyak kegagalan, maka guru harus memberikan banyak keberhasilan bagi siswa. Tentu saja, harapan itu masuk akal. Karena harapan yang tidak realistis adalah kebohongan dan hal itu tidak disukai oleh siswa.

c. Memberikan insentif

Bila siswa berhasil, guru diharapkan memberi hadiah kepada murid mereka (bisa dalam bentuk pujian, nilai yang bagus, dll) demi kesuksesan mereka,sehingga siswa terdorong untuk melakukan lebih banyak upaya untuk mencapai tujuan pendidikan.

d. Mengarahkan perilaku siswa

27 Sardiman, Interaksi dan Motivasi Belajar Mengajar.... Hal. 89-91.

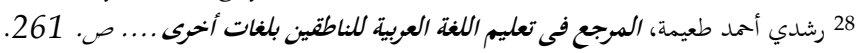

29 Syaiful Bahri Djamarah, Psikologi Belajar. (Jakarta: Rineka Cipta, 2002). Hal. 169. 
Cara mengarahkan perilaku siswa adalah memberikan tugas dan pendekatan serta memberikan hukuman pendidikan dan teguran dengan sikap lembut dan dengan kata yang ramah dan baik.

Sardiman mengatakan bahwa ada bentuk dan cara untuk meningkatkan motivasi siswa dalam proses pembelajaran di sekolah: ${ }^{30}$

a. Memberi angka

Angka biasanya merupakan tujuan bagi siswa untuk belajar. Ini adalah hal yang baik yang akan menyebabkan motivasi belajar. Ini akan menjadi lebih baik jika siswa tidak diajarkan untuk mencapai angka yang berhubungan dengan aspek kognitif saja tapi juga aspek keterampilan dan afeksinya.

b. Hadiah dalam bentuk barang berharga

Hadiah dalam bentuk barang bisa dikatakan sebagai motivasi, tetapi tidak selalu demikian. Karena hadiah untuk suatu pekerjaan, mungkin tidak akan menarik bagi seseorang yang tidak senang dan tidak berbakat untuk sesuatu pekerjaan tersebut.

c. Saingan/kompetisi

Persaingan bisa dijadikan motivasi untuk mendorong pembelajaran siswa.

d. Ego-involvement

Menumbuhkan kesadaran kepada siswa untuk merasakan pentingnya tugas dan menerimanya sebagai tantangan sehingga bekerja keras dengan mempertaruhkan harga diri, adalah sebagai salah satu bentuk motivasi yang penting.

e. Memberi ulangan

Para siswa akan menjadi giat belajar kalau mengetahui akan ada ulangan. Oleh karena itu pemberian ulangan ini juga merupakan sarana motivasi.

f. Mengetahui hasil

Dengan mengetahui hasil pekerjaan, apalagi kalau terjadi kemajuan, akan mendorong siswa untuk lebih giat belajar. Ilnya Semakin mengetahui bahwa grafik belajar meningkat, maka ada motivasi pada diri siswa yang sama untuk terus belajar, dengan suatu harapan hasilnya terus meningkat.

g. Pujian

Apabila ada siswa yang sukses yang berhasil menyelesaikan tugas dengan baik, perlu diberikan pujian. Pujian ini adalah bentuk reinforcement positif dan sekaligus merupakan motivasi yang baik.

h. Hukuman

Hukuman sebagai reinforcement yang negatif tetapi kalau diberikan secara tepat dan bijak bisa menjadi alat motivasi.

i. Hasrat untuk belajar

30 Sardiman, Interaksi dan Motivasi Belajar Mengajar.... Hal. 92-95 
Hasrat untuk belajar, berarti ada unsur kesengajaan, ada maksud untuk belajar.

j. Minat

Motivasi memiliki hubungan erat dengan minat. Minat adalah motivasi yang pokok. Proses pembelajaran akan berjalan dengan baik apabila disertai dengan minat.

k. Tujuan yang diakui

Rumusan tujuan yang diakui dan diterima baik oleh siswa, akan merupakan alat motivasi yang sangat penting.

Motivasi belajar siswa dipengaruhi oleh beberapa faktor yang terbagi menjadi faktor internal dan faktor eksternal. ${ }^{31}$

a. Faktor internal (berasal dari dalam diri siswa)

a) Faktor fisik

Faktor fisik meliputi antara lain: nutrisi (gizi), kesehatan, fungsi fisik (terutama lima indera).

b) Faktor psikologis

Faktor psikologis berhubungan dengan aspek yang mendorong atau menghambat aktivitas belajar siswa.

b. Faktor eksternal (berasal dari lingkungan)

a) Faktor non-sosial

Faktor non-sosial yang terlibat, seperti: cuaca (cuaca panas atau dingin), waktu (pagi, siang, malam) dan lokasi (tenang, ribut, atau kualitas sekolah dimana belajar) dan sarana prasarana. Bila semua faktor bisa saling mendukung dalam proses pembelajaran maka akan berjalan dengan baik.

b) Faktor sosial

Faktor sosial adalah faktor manusia (guru, konselor, orang tua), baik yang hadir secara langsung maupun tidak langsung.

Adapun faktor-faktor yang mempengaruhi motivasi belajar menurut Dimyati dan Mudjiono adalah sebagai berikut: ${ }^{32}$

a. Cita-cita atau aspirasi siswa

Setiap manusia memiliki cita-cita atau aspirasi tertentu dalam hidupnya, termasuk belajar. Gagasan selalu diikuti dan dipertahankan Terlepas dari tantangan yang mereka hadapi dalam menjalankan cita-cita ini, seseorang akan melakukan yang terbaik melalui tantangan ini untuk tujuan yang ingin dicapainya. Dalam hal ini cita-cita akan mendorong motivasi belajar baik secara internal maupun eksternal. Karena dengan tercapainya cita-cita akan mewujudkan realisasi diri. Oleh karena itu, cita-cita dan aspirasi sangat berpengaruh terhadap motivasi belajar seseorang.

31 Yusuf Syamsu, Program Bimbingan dan Konseling di Sekolah. (Bandung: Rizqi Press). Hal. 30.

32 Dimyati dan Mudjiono, Belajar dan Pembelajaran. (Jakarta: Rineka Cipta, 1999). Hal. 78. 
b. Kemampuan siswa

Keinginan siswa harus disertai kemampuan mencapainya. Keinginan membaca perlu disertai tiga puluh kemampuan untuk mengenali huruf dan mengucapkan bunyinya. Keberhasilan membaca buku bacaan akan menambah kekayaan pengalaman hidup. Singkatnya, dapat dikatakan bahwa kemampuan akan meningkatkan motivasi siswa untuk melakukan tugas perkembangan.

c. Keadaan siswa

Keadaan fisik dan spiritual siswa mempengaruhi motivasi belajar. Seorang siswa yang sakit, lapar atau marah akan mengganggu perhatian belajar. Sebaliknya, akan mudah untuk fokus pada siswa yang sehat, kenyang dan bahagia. Siswa yang menderita penyakit ini akan ragu untuk belajar. Seorang siswa yang marah akan sulit berkonsentrasi untuk menafsirkan pelajaran. Sebaliknya, setelah siswa itu sehat dia akan mengejar pelajaran. Siswa senang membaca buku teks untuk mendapatkan nilai bagus, seperti sebelum sakit. Seseorang yang sebelumnya memiliki motivasi belajar tinggi, tiba-tiba menjadi rendah karena kondisi fisik dan semangatnya terganggu. Dengan kata lain, status fisik dan spiritual siswa adalah motivasi belajar.

d. Kondisi lingkungan siswa

Lingkungan siswa bisa berupa alami, perumahan, rekan dan kehidupan sosial. Sebagai anggota masyarakat siswa bisa terkena dampak lingkungan sekitar. Bencana alam, perumahan lusuh, ancaman dan perang saudara yang buruk di kalangan siswa, akan mengganggu keseriusan belajar. Sebaliknya, sekolah yang indah dan asosiasi siswa yang harmonis akan meningkatkan motivasi belajar. Karena itu, keadaan lingkungan sekolah yang sehat dan harmoni kehidupan, ketertiban dan perawatan sosial perlu diperkuat. Dengan lingkungan yang aman, damai, terorganisir dan indah maka akan meningkatkan semangat dan motivasi belajar dengan mudah.

e. Unsur dinamis dalam pembelajaran

Siswa memiliki perasaan, minat, kehendak, pikiran dan gagasan yang berubah melalui pengalaman hidup. Pengalaman dengan teman sebaya mempengaruhi motivasi dan perilaku belajar. Lingkungan siswa juga berubah dalam bentuk lingkungan alam, lingkungan tempat tinggal dan perhimpunan. Lingkungan budaya siswa berupa koran, majalah, radio, televisi dan film semakin banyak siswa semakin bertambah. Semua lingkungan ini secara dinamis merangsang pembelajaran.

f. Upaya guru untuk membuat siswa belajar

Upaya guru dilakukan untuk mengajar siswa di sekolah dan di luar sekolah. Upaya belajar di sekolah meliputi:

a) Mengatur sebuah pembelajaran yang terorganisir di sekolah 
b) Memperkuat disiplin dalam belajar di setiap kesempatan, seperti memanfaatkan waktu dan pemeliharaan fasilitas sekolah.

c) Memperkuat pembelajaran disiplin sosial.

d) Memperkuat pembelajaran terstruktur lingkungan sekolah

Upaya guru di sekolah tidak lepas dari kegiatan di luar sekolah. Pusat pendidikan di luar sekolah adalah keluarga, lembaga keagamaan, pramuka, dan pusat pendidikan pemuda lainnya. Siswa sekolah umumnya diintegrasikan ke dalam pusat-pusat ini. Guru profesional diminta untuk menjalin kerjasama pendidikan dengan pusat pendidikan ini.

Salah satu faktor yang berbeda yang mempengaruhi keseluruhan motivasi belajar pada umumnya meliputi faktor internal yang berasal dari dalam diri siswa dan faktor eksternal yang berasal dari luar siswa yang sama. Secara internal siswa akan termotivasi jika dia memiliki tubuh mental yang sehat dan memiliki cukup cita-cita dan kemampuan. Secara eksternal, siswa akan termotivasi jika lingkungan atau keadaan sekitarnya baik dalam bentuk orang atau orang lain mendukung siswa untuk belajar. Misalnya tempat yang nyaman, cuaca yang menyenangkan, guru atau orang tua yang membangun siswa atau anak.

\section{Pengaruh Pemberian Reward dalam Meningkatkan Motivasi Belajar Siswa Pada Mata Pelajaran Bahasa Arab}

\section{a. Uji Normalitas}

Uji normalitas dilakukan untuk mengetahui apakah data berdistribusi normal atau tidak. Pada pembahasan ini, uji normalitas dilakukan dengan menggunakan uji Kolmogorov-Smirnova.

Dasar pengambilan keputusan dalam pengujian normalitas pemberian reward dan Motivasi siswa dalam belajar Bahasa Arab dengan menggunakan uji Kolmogorov-Smirnov a yaitu :

- Nilai sig. atau signifikansi atau nilai probabilitas $>0,05$, maka data berdistribusi normal.

- Nilai sig. atau signifikansi atau nilai probabilitas $<0,05$, maka data berdistribusi data tidak normal.

One-Sample Kolmogorov-Smirnov Test

\begin{tabular}{|c|c|c|c|}
\hline & & $\begin{array}{l}\text { Pemberian } \\
\text { reward }\end{array}$ & $\begin{array}{lr}\text { Motivasi } & \text { siswa } \\
\text { dalam } & \text { belajar } \\
\text { Bahasa Arab } & \end{array}$ \\
\hline \multirow[t]{2}{*}{$\mathrm{N}$} & & 20 & 20 \\
\hline & Mean & 64.7000 & 66.2000 \\
\hline \multirow[t]{2}{*}{ Normal Parameters ${ }^{\mathrm{a}, \mathrm{b}}$} & Std. & 4.58946 & 6.40395 \\
\hline & Deviation & & \\
\hline \multirow{3}{*}{$\begin{array}{l}\text { Most } \\
\text { Differences }\end{array}$} & Absolute & .144 & .150 \\
\hline & Positive & .144 & .150 \\
\hline & Negative & -.126 & -.117 \\
\hline
\end{tabular}


\begin{tabular}{|l|l|l|} 
Kolmogorov-Smirnov Z & .646 & .672 \\
Asymp. Sig. (2-tailed) & .798 & .757 \\
\hline
\end{tabular}

a. Test distribution is Normal.

b. Calculated from data.

Hasil uji normalitas pada tabel test of normality di atas data pemberian reward menunjukkan nilai signifikan pada uji kolmogorov sebesar 0,798. Karena tersebut nilai signifikan berada di atas 0,05. Maka data Pemberian reward berdistribusi normal.

Uji normalitas Motivasi siswa dalam belajar Bahasa Arab menunjukkan nilai signifikan pada uji kolmogorov sebesar 0,757. Karena nilai signifikan berada di atas 0,05. Maka data Motivasi siswa dalam belajar Bahasa Arab berdistribusi normal.

b. Uji Linieritas

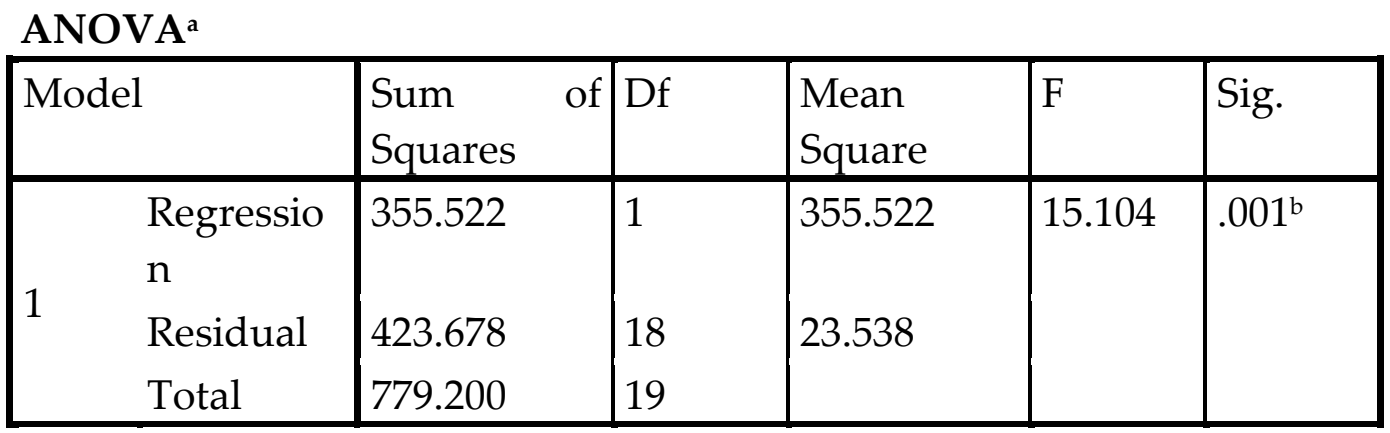

a. Dependent Variable: Motivasi siswa dalam belajar Bahasa Arab

b. Predictors: (Constant), Pemberian reward

Hasil uji anova tersebut menunjukkan bahwa nilai $\mathrm{F}$ hitung sebesar 15,104 dengan taraf signifikansi sebesar 0,001. Nilai ini kemudian dibandingkan dengan $\mathrm{F}$ tabel yang dihitung pada derajat bebas pembilang (df pembilang) sebesar 1 dan derajat bebas penyebut (df penyebut) sebesar 18 pada taraf 0,05 yang nilainya adalah 4.41 . Tampak sangat jelas bahwa nilai Fhitung $(15,104)$ lebih besar dari Ftabel $(4.41)$. Sehingga dapat disimpulkan bahwa model yang dihasilkan adalah baik. Hal ini menunjukkan model regresi linear dapat digunakan.

c. Uji Determinasi

Model Summary

\begin{tabular}{|l|l|l|l|l|}
\hline $\begin{array}{l}\text { Mode } \\
1\end{array}$ & $\mathrm{R}$ & $\begin{array}{l}\mathrm{R} \\
\text { Square }\end{array}$ & $\begin{array}{l}\text { Adjusted R R } \\
\text { Square }\end{array}$ & $\begin{array}{l}\text { Std. Error of } \\
\text { the Estimate }\end{array}$ \\
\hline 1 & $.675^{\mathrm{a}}$ & .456 & .426 & 4.85156 \\
\hline
\end{tabular}

a. Predictors: (Constant), Pemberian reward 
Pada tabel di atas terdapat $\mathrm{R}$ Square sebesar 0,456 (kuadrat dari koefisien korelasi 0,675). R Square disebut koefisien determinan yang dalam hal ini 45,6\%. Dari nilai tersebut dapat diartikan bahwa 45,6\% Pengaruh pemberian reward dalam meningkatkan motivasi belajar siswa pada mata pelajaran bahasa Arab sedangkan sisanya dipengaruhi oleh faktor lain

d. Uji Regresi Sederhana

Coefficients ${ }^{a}$

\begin{tabular}{|l|l|l|l|l|l|}
\hline \multirow{2}{*}{ Model } & \multicolumn{2}{|l|}{$\begin{array}{l}\text { Unstandardized } \\
\text { Coefficients }\end{array}$} & $\begin{array}{l}\text { Standardize } \\
\text { d } \\
\text { Coefficients }\end{array}$ & T & Sig. \\
\cline { 2 - 6 } & B & Std. Error & Beta & & \\
\hline $\begin{array}{l}\text { (Constant) } \\
\text { Pemberian reward }\end{array}$ & 5.218 & 15.728 & & .332 & .744 \\
\hline
\end{tabular}

a. Dependent Variable: Motivasi siswa dalam belajar Bahasa Arab

$\mathbf{Y}=\mathbf{a}+\mathbf{b X}$

Y adalah variabel dependent, dalam hal ini adalah motivasi siswa dalam belajar Bahasa Arab, dan X adalah variabel independent, dalam hal ini adalah pemberian reward. Sedangkan a dan b adalah nilai konstanta yang dicari.

Berdasarkan hasil regrasi diketahui nilai constant-nya adalah 5,218 dan nilai motivasi siswa dalam belajar Bahasa Arab adalah 0,943. Dari keterangan tersebut kita dapat memperoleh persamaan regresi sebagai berikut:

$\mathbf{Y}=5,218+0,843 \mathbf{X}$

Nilai konstanta dari koefficien regresi sebesar 5,218, hal ini menyatakan bahwa jika tidak ada kenaikan nilai atau skor dari variabel Pemberian reward, maka variabel Pemberian reward adalah 5,218. Koefficien regresi sebesar 0,843 menyataakan bahwa setiap terjadi penambahan skor variabel Pemberian reward akan dapat menambah kenaikan variabel Motivasi siswa dalam belajar Bahasa Arab.

\section{e. Uji Hipotesis}

Setelah mengetahui besarnya koefisien regresi, maka perlu dilakukan pengujian hipotesis untuk megetahui apakah terdapat pengaruh atau tidak. Uji hipotesis dapat dinyatakan dengan membandingkan nilai signifikan yaitu:

Jika nilai signifikan $>0,05$ dan thitung $<t_{\text {tabel, }}$ maka $\mathrm{H}_{0}$ diterima

Jika nilai signifikan $<0,05$ dan thitung $<$ tabel, maka $\mathrm{H}_{0}$ ditolak

Jika tabel dicari dengan $\alpha=0,05$ dan (df) n-k-1 atau 20-2-1 = 17, jadi tabel $=$ 1.73961

Berdasarkan hasil uji regresi di atas nilai signifikan sebesar 0,001. Karena nilai signifikan lebih kecil dari 0,05 dan $t$ hitung $(3,886)$ lebih besar 
dari t tabel (1.73961) maka Ho ditolak, artinya bahwa ada pengaruh pemberian reward terhadap motivasi siswa dalam belajar Bahasa Arab.

\section{Kesimpulan}

Berdasarkan penelitian yang telah dilakukan oleh peneliti maka dapat disimpulkan bahwa:

a. Pola pemberian reward. Peneliti melakukan observasi pembelajaran Bahasa Arab di MTs Darul Masholeh Cirebon tanpa menerapkan pemberian hadiah. Peneliti mengamati proses pembelajaran dari awal sampai akhir, sehingga menemukan bahwa banyak siswa yang kurang bersemangat dalam mengikuti pembelajaran. Kemudian peneliti melakukan observasi partisipan melalui mengajar dengan menerapkan reward kepada siswa selama tiga pertemuan. Reward diberikan kepada siswa yang memiliki prestasi. Prestasi tersebut yaitu siswa yang hafal semua kosa kata yang diberikan, siswa yang bisa menjawab pertanyaan dengan benar dan siswa yang mengerjakan tugas. Setelah pembelajaran dilakukan dari pertemuan pertama sampai ketiga kemudian siswa diberi post test dalam bentuk angket untuk mengukur motivasi belajar siswa dengan adanya reward.

b. Persepsi siswa terhadap reward dalam meningkatkan motivasi siswa di kelas VIII di MTs Darul Masholeh Cirebon. Berdasarkan hasil kesimpulan angket positif menunjukkan bahwa siswa yang menjawab sangat setuju $43 \%$, setuju $46 \%$, tidak setuju $8 \%$, dan sangat tidak setuju 3\%. Dan berdasarkan angket negatif siswa yang menjawab sangat setuju $1 \%$, setuju $20 \%$, tdak setuju $43 \%$, dan sangat tidak setuju 36\%. Oleh karena itu pemberian reward dapat meningkatkan motivasi siswa dalam pembelajaran Bahasa Arab.

c. Dari data yang ada terdapat pengaruh pemberian reward terhadap motivasi siswa dalam belajar Bahasa Arab. Hal ini berdasarkan hasil uji regresi dengan hasil 0,001. Karena hasilnya lebih kecil dari 0,05 dan t hitung $(3,886)$ lebih besar dari $t$ tabel $(1,73961)$, maka Ho ditolak dan Ha diterima. Ini berarti pemberian hadiah mempengaruhi motivasi belajar bahasa Arab. 


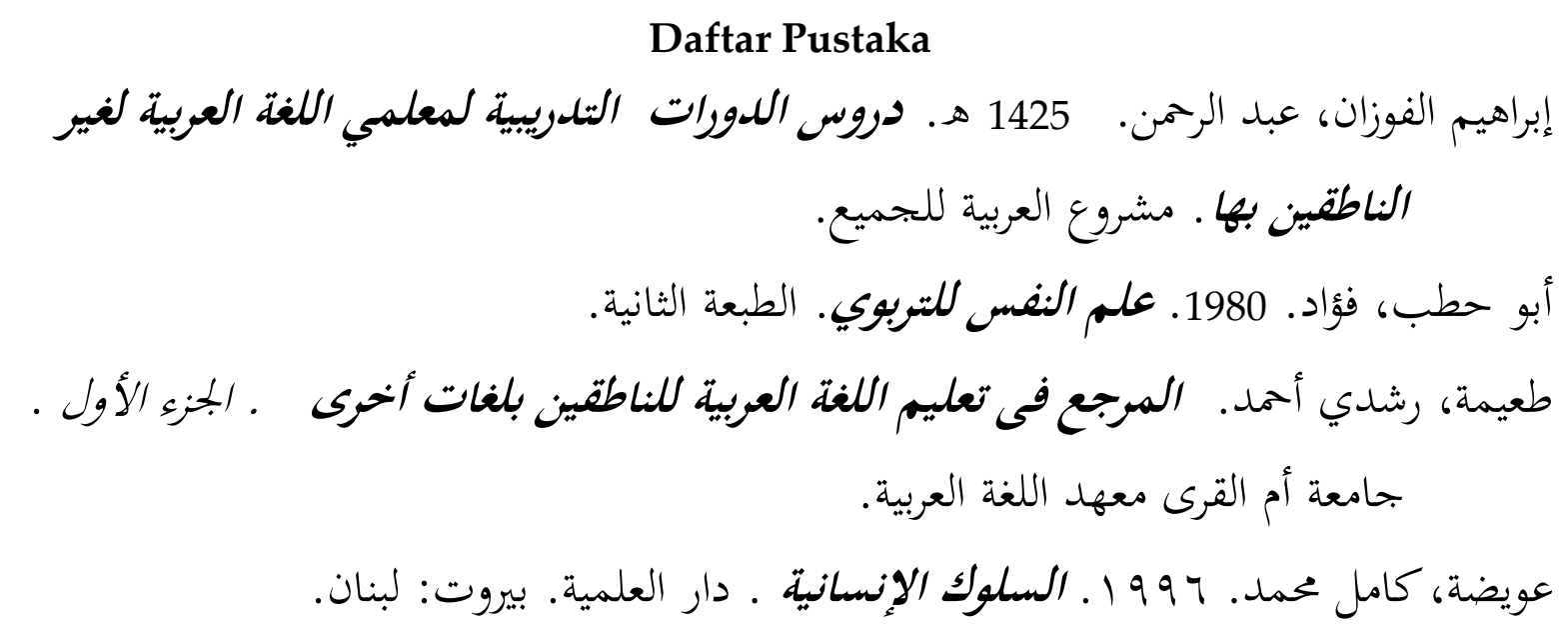

\section{Referensi Bahasa Indonesia}

Arifin, HM. 2009. Ilmu Pendidikan Islam. Jakarta: Bumi Aksara.

Arikunto, Suharsimi. 2010. ProsedurPenelitian Suatu Pendekatan Praktik. Jakarta: PT Rineka Cipta.

Budiningsih, C. Asri. 2005 .Belajar dan Pembelajaran. Jakarta: PT Rineka Cipta.

Dahar, Ratna Wilis. 2011. Teori-teori Belajar dan Pembelajaran. Jakarta : Erlangga.

Desmita.2011. Psikologi Perkembangan Peserta Didik. Bandung: Remaja Rosdakarya.

Dimyati dan Mudjiono. 1999. Belajar dan Pembelajaran. Jakarta: Rineka Cipta.

Djamarah, Syaiful Bahri. 2002. Psikologi Belajar.Jakarta: Rineka Cipta.

Gibson. 1999. Organisasi, Perilaku, Stuktur, dan Proses. Jakarta: Erlangga

Hamalik, Oemar. 2011. Kurikulum dan Pembelajaran. Jakarta : Bumi Aksara.

Purwanto, Ngalim. 2007. Ilmu Pendidikan Teoritis dan Praktis. Bandung: PT

Remaja Rosdakarya

----------. 2007.Psikologi Pendidikan. Bandung. Remaja Rosdakarya.

Rusmono. 2012. Strategi Pembelajaran dengan Problem Based Learning Itu Perlu.

Bogor : Ghalia Indonesia.

Sardiman. 2014. Interaksi dan Motivasi Belajar Mengajar. Jakarta : Rajawali Press.

Shoimin, Aris. 2014. 68 Model Pembelajaran Inovatif dalam Kurikulum 2013. Yogyakarta : Ar-Ruzz Media.

Siregar, Eveline \& Hartini Nara. 2011. Teori Belajar dan Pembelajaran. Bogor:

Ghalia Indonesia

Slameto. 2010. Belajar dan Faktor-Faktor yang Mempengaruhinya. Jakarta : Rineka Cipta.

Sugiyono. 2015. Metode Penelitian Pendidikan. Bandung: Alfabeta. 2016. Metode Penelitian Manajemen. Bandung: Alfabeta.

Syamsu, Yusuf. 2009. Program Bimbingan dan Konseling di Sekolah. Bandung: Rizqi Press. 